\title{
Metaxanine, A Systemic Fungicide Against Plasmopara Viticola on Wine Grapes: Disease Control, Residues and Effect on Fermentation and Wine Quality
}

\author{
P. G. MARAIS and A. TROMP \\ Oenological and Viticultural Research Institute, Stellenbosch, 7600, South Africa
}

The Technical assistance of J. Sutherland, H. S. van der Walt and Adrian Kirschbaum is gratefully acknowledged. The authors also wish to thank Ciba Geigy, South Africa for their aid.

\begin{abstract}
The systemic fungicide metaxanine/methyl D, L-N-(2,6-dimethyl-phenyl)-N-(2 methoxyacetyl) alaninate/, was compared with mancozeb for the control of Plasmopara viticola $(B \times C)$ Berl. \& de $T$. on grapevines in the Western Cape Province of South Africa. The systemic fungicide gave better control than mancozeb. Good control was obtained with applications of the systemic fungicide at 21 day intervals, despite the fact that weather conditions were particularly favourable for disease development. Residues of metaxanine recovered from grapes were low and did not affect either the onset, or the rate of fermentation of grape juice, nor did it affect wine quality.
\end{abstract}

Grapevine downy mildew, caused by Plasmopara viticola (B \& C) Berl. \& de T. can become epidemic in South Africa in some seasons. Various fungicides are used to combat the disease, copper and dithiocarbamate compounds being the most popular (Marais, 1977). However, effectiveness is largely affected by the weather conditions during the growing season and control is unsatisfactory under prolonged conditions favourable for the development of the disease. In recent trials in Europe good control was achieved with various systemic fungicides (Meyer, Brechbuhler, \& Weber, 1978; Mur, 1978; Shiller, Raspé \& Fritzsche, 1979). One of these systemic fungicides has been tested under South African conditions and good control was obtained despite the fact that weather conditions were particularly favourable for disease development (Marais \& Van der Walt, 1978). As downy mildew can be a problem shortly before harvest in summer rainfall areas and in vineyards under irrigation, it is sometimes necessary to use a fungicide at this late stage. The choice of fungicides which can be used at such a late stage is limited because of the detrimental effects which residues of certain fungicides have on alcoholic fermentation (Ehrenhardt \& Jakob, 1968b; Rágala \& Minárik, 1971).

A new systemic fungicide metaxanine $\mathrm{a}^{\mathrm{a}} / \mathrm{methyl}^{\mathrm{D}}, \mathrm{L}-\mathrm{N}-$ (2,6-dimethyl-phenyl)-N-(2 methoxyacetyl) alaninate/ was therefore evaluated in field and laboratory trials under South African conditions to determine whether better control of $P$. viticola can be achieved and whether this fungicide has any detrimental effect on alcoholic fermentation and wine quality.

\section{MATERIALS AND METHODS}

Disease control: Three types of experiments were conducted viz.

(a) The minimum effective dose was determined by spraying Tinta Barocca vines seven times at $14 \mathrm{~d}$ intervals with five concentrations of metaxanine as indicated in Table 1. The percentage leaf infection was determined $7 d$ after the final spray.

(b) The efficacy of metaxanine WP50 (15\% metaxanine $+35 \%$ copper oxychloride) was compared to that of a traditional spray material, mancozeb, in two experiments on Chenin blanc and Riesling. The different application frequencies are outlined in Table 2. These sprays were all applied by motorized knapsack sprayers and their efficacy was assessed immediately prior to harvest.

(c) The efficacy of metaxanine as a curative fungicide against $P$. viticola was compared to that of mancozeb in a nursery on vines already infected with downy mildew. Assessment of leaf infection was done at the commencement of the trial. Thereafter the different fungicides were applied, once only, two times with a $7 \mathrm{~d}$ interval and three times with $14 \mathrm{~d}$ intervals. The control plots were left untreated. Each treatment was replicated eight times in randomized blocks and treatment plots were $15 \mathrm{~m}^{2}$

In both the experiments (a) and (b) spraying started when the longest shoots were $100 \mathrm{~mm}$ long, the sprays applied at a pressure of $200 \mathrm{kPa}$. A randomized block design with four replicates of five vines each per treatment was used.

In all experiments the degree of infection was assessed according to the method of Unterstenhöfer (1963) and statistical significance of differences between treatments were tested by means of Duncan's multiple range test (Harter, 1960).

Residue studies: Three residue trials, the cultivars Pinotage, Colombard and Cabernet sauvignon were sprayed with metaxanine $30 \mathrm{~g}$ active ingredient (a.i.) + copper oxychloride (50 g a.i.)/100 $\ell$ of water. The vines were sprayed ten times at $14 \mathrm{~d}$ intervals until four weeks before harvest. The grapes from replicate plots were pooled and wine was made from a representative sample, according to standard wine-making procedures used by the Oenolo- 
gical and Viticultural Research Institute. Frozen grapes, as well as bottled wine samples were analysed for residue by Ciba Geigy, South Africa.

Additional trials for residue determinations on Cabernet sauvignon and Colombard were carried out in the 1978/79 season. Plots of four vines each (four replicates per treatment), were sprayed eight times with metaxanine (30 g a.i.) + copper oxychloride $(70 \mathrm{~g}$ a.i. $) / 100 \ell$ of water at $14 \mathrm{~d}$ intervals. Grape samples were taken immediately after the treatment (Od) and subsequently 1,2 , $4,8,16,23$ and $32 \mathrm{~d}$ after application. Samples from the replicate plots were pooled, frozen and analysed for residues by Ciba Geigy, South Africa.

Fermentation studies: Laboratory fermentations, based on methods described by Ehrenhardt \& Jakob (1968a) were made in triplicate at $25^{\circ} \mathrm{C}$ using $100 \mathrm{~m} \ell$ sterilized Colombard grape juice in $250 \mathrm{~m} \ell$ Erlenmeyer flasks fitted with fermentation locks. The Colombard grape juice was obtained from grapes which had received ten sprays with $14 \mathrm{~d}$ intervals between sprays with metaxanine $30 \mathrm{~g}$ a.i./ $100 \ell$. The yeast inoculum consisted of $0,2 \mathrm{~g}$ active dried yeast/ $\ell$ juice (Saccharomyces cerevisiae strain WE 14) and the subsequent fermentation activity was determined by measuring daily mass loss.

Wine quality: Experimental wines were made in duplicate (10 $\ell$ containers) from Pinotage, Colombard and Cabernet sauvignon grapes which had been sprayed ten times with metaxanine at $14 \mathrm{~d}$ intervals until four weeks before harvest, in the cellars of the Oenological and Viticultural Research Institute using standard winemaking procedures. Unsprayed grapes were used to make a control wine. The wines were presented to a panel of judges and evaluated for overall wine quality.

\section{RESULTS AND DISCUSSION}

Disease control: From Table 1 it is clear that 2,4 and 8 $\mathrm{g} / \ell$ applications resulted in a significant lower infection than the $1 \mathrm{~g} / \ell$ treatment and the control, while the $4 \mathrm{~g} / \ell$ and $8 \mathrm{~g} / \ell$ treatment resulted in significant lower infections than all other treatments. There were no further significant differences among the treatments.

\section{TABLE 1}

Mean leaf infection of grapevine by Plasmopara viticola after treatment with different concentrations of metaxanine

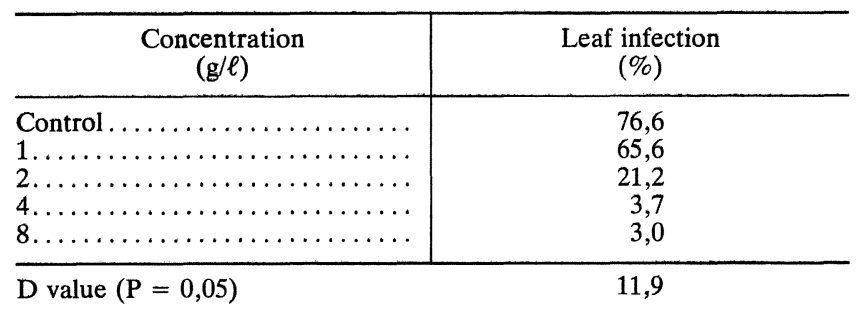

(b) The discussion of the trials in which metaxanine was compared to a traditional spray material is summarised in Table 2 .
TABLE 2

Mean leaf infection of grapevine by Plasmopara viticola after various fungicidal applications at $14 \mathrm{~d}$ and at $21 \mathrm{~d}$ intervals

\begin{tabular}{l|c|c|c}
\hline \multicolumn{1}{c|}{ Fungicide } & $\begin{array}{c}\text { Interval between } \\
\text { applications } \\
\text { (d) }\end{array}$ & Cultivar & $\begin{array}{c}\text { Leaf } \\
\text { infection } \\
(\%)\end{array}$ \\
\hline Control ........ & - & Chenin blanc & 42,0 \\
Mancozeb ...... & 14 & $\begin{array}{c}\text { Chenin blanc } \\
\text { Chenin blanc }\end{array}$ & 14,8 \\
Metaxanine W.P. 50 & 14 & Chenin blanc & 21,2 \\
Mancozeb ...... & 21 & Chenin blanc & 6,4 \\
Metaxanine W.P. 50 & 21 & & 7,2 \\
D. value (P=0.05) & & Riesling & 72,6 \\
Control........ & - & Riesling & 39,2 \\
Mancozeb ...... & 14 & Riesling & 6,4 \\
Metaxanine W.P.50 & 14 & Riesling & 46,9 \\
Mancozeb ...... & 21 & 13,7 \\
Metaxanine W.P.50 & 21 & & 17,3 \\
\hline D. value (P =0.05) & &
\end{tabular}

In both trials all the metaxanine treatments were significantly better than the control as well as the mancozeb treatments. In both trials the metaxanine as well as the mancozeb applied at $14 \mathrm{~d}$ intervals did not differ statistically from the same treatments applied at $21 \mathrm{~d}$ intervals.

(c) Results of the trial to test the efficacy of metaxanine as a curative fungicide against downy mildew are summarised in Table 3.

TABLE 3

Mean leaf infection of grapevine by Plasmopora viticola before and after different fungicidal treatments.

\begin{tabular}{|c|c|c|c|}
\hline Treatment & $\begin{array}{l}\text { Interval } \\
\text { between } \\
\text { applications } \\
\text { (d) }\end{array}$ & $\begin{array}{l}\text { Leaf } \\
\text { infection } \\
\text { before } \\
\text { treatment } \\
(\%)\end{array}$ & $\begin{array}{l}\text { Leaf } \\
\text { infection } \\
\text { after } \\
\text { treatment } \\
(\%)\end{array}$ \\
\hline 1 spray & & & \\
\hline $\begin{array}{l}\text { Control ........... } \\
\text { Mancozeb ....... } \\
\text { Metaxanine W.P. } 50 \\
\text { D Value }(P=0,05)\end{array}$ & $\begin{array}{l}- \\
0 \\
0\end{array}$ & $\begin{array}{l}38,0 \\
38,4 \\
38,0\end{array}$ & $\begin{array}{l}59,4 \\
42,3 \\
23,6\end{array}$ \\
\hline \multicolumn{4}{|l|}{2 sprays } \\
\hline $\begin{array}{l}\text { Control ........... } \\
\text { Manzozeb ....... } \\
\text { Metaxanine W.P. } 50 \\
\text { D. value }(P=0,05)\end{array}$ & $\begin{array}{l}-7 \\
7\end{array}$ & $\begin{array}{l}32,0 \\
32,8 \\
33,6\end{array}$ & $\begin{array}{l}63,9 \\
39,6 \\
12,0\end{array}$ \\
\hline \multicolumn{4}{|l|}{3 sprays } \\
\hline $\begin{array}{l}\text { Control ........... } \\
\text { Mancozeb ........ } \\
\text { Metaxanine W.P. } 50 \\
\text { D Value }\end{array}$ & $\begin{array}{l}\overline{14} \\
14\end{array}$ & $\begin{array}{l}34,6 \\
33,2 \\
33,4\end{array}$ & $\begin{array}{r}55,8 \\
40,2 \\
9,0\end{array}$ \\
\hline
\end{tabular}

All the metaxanine treatments resulted in less leaf infection after treatment than before. The percentage leaf infection in both the control and mancozeb treatments were higher than the prespray infection.

Residue studies: Residue of metaxanine on Pinotage, Colombard and Cabernet sauvignon grapes and in their wines are shown in Table 4. Results of residues recovered from Colombard and Cabernet sauvignon grapes as determined at various intervals after the final applications, are shown in Fig. 1. 
TABLE 4

Metaxanine residues recovered from treated and untreated Pinotage, Colombard and Cabernet sauvignon grapes and wine.

\begin{tabular}{c|cc}
\hline Cultivar & \multicolumn{2}{|c}{ Residues $(\mathrm{mg} / \ell)^{\mathrm{a}}$ in } \\
Wrapes
\end{tabular}

a-Mean of two determinations.

ND-None detected.

Fermentation studies: The effect of ten metaxanine $30 \mathrm{~g}$ a.i./100 $\ell$ sprays up to four weeks before harvest on alcoholic fermentation of Colombard grape juice at $25^{\circ} \mathrm{C}$ are illustrated in Fig. 2. No significant differences were found in the fermentation rates of musts from treated and untreated grapes.

Wine quality: The wine evaluation data are presented in Table 5.

TABLE 5

Wine quality rating for wines made from grapes sprayed with metaxanine and unsprayed grapes.

\begin{tabular}{|c|c|c|}
\hline Cultivar & Treatment & $\begin{array}{l}\text { Wine Quality } \\
\text { rating } \\
(\%)\end{array}$ \\
\hline & $\begin{array}{c}\text { Control } \\
\text { Metaxanine }\end{array}$ & $\begin{array}{l}61,7 \\
60,0\end{array}$ \\
\hline Pinotage ...... & $\begin{array}{c}\text { Control } \\
\text { Metaxanine }\end{array}$ & 53,9 \\
\hline Cabernet sauvignon...... & $\begin{array}{c}\text { Control } \\
\text { Metaxanine }\end{array}$ & $\begin{array}{l}80,0 \\
75,3\end{array}$ \\
\hline
\end{tabular}

L.S.D. $(P=0,05)$ 8,5

FIG. 1

Breakdown of metaxanine residues in Cabernet sauvignon and Colombard grapes after eight applications of 30 g.a.i./100 $\ell$.

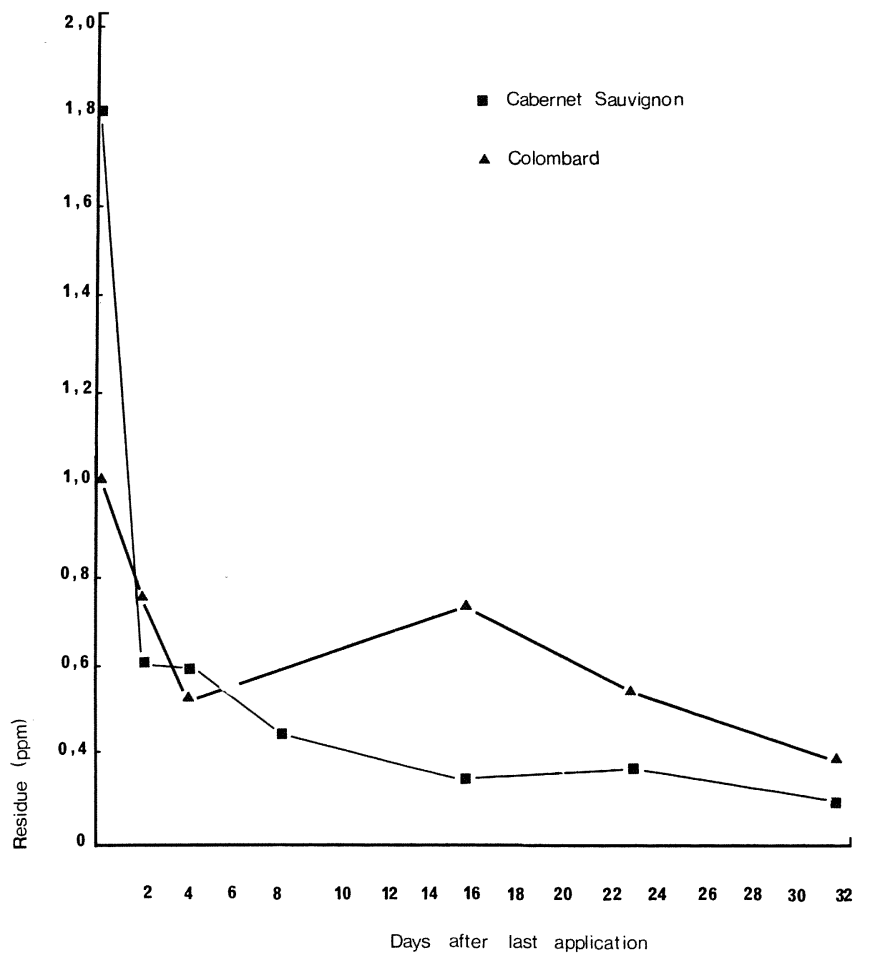

From the data it is evident that spraying of grape vines with metaxanine had no detrimental effect on wine quality.

\section{CONCLUSIONS}

In field trials metaxanine gave effective control of $P$. viticola on grapevines. Lower percentage infection were obtained than with the standard fungicide applied at the same time intervals. Where metaxanine was applied on vines already infected with downy mildew, the leaf infection after treatment was significantly lower than that following treatment with the standard fungicides. In all cases the final infection was lower than that of the initial infection. This indicates a curative property of metaxanine, but although use can be made of this property prior to flowering, curative treatments after fruits have been attacked will not save an infected crop. In the present study very little residual metaxanine was found either on treated grapes, or in the wine. Most of the residue recovered from the grapes are removed during the vinification processes of the must and wine, resulting in very low residues in the bottled product.

Metaxanine did not affect the fermentation process or the wine quality and it can be concluded that with intervals between applications as long as $21 \mathrm{~d}$, even if prolonged rains or sprinkling irrigation occur after application, good control of $P$. viticola is ensured. Low residues can be expected on grapes and in wine and no detrimental eff́ect on alcoholic fermentation or wine quality is likely to occur.
FIG. 2

Fermentation curves of Colombard must from grapes after eight applications of metaxanine WP 2530 g.a.i./100 $\ell$ and must from untreated Colombard grapes.

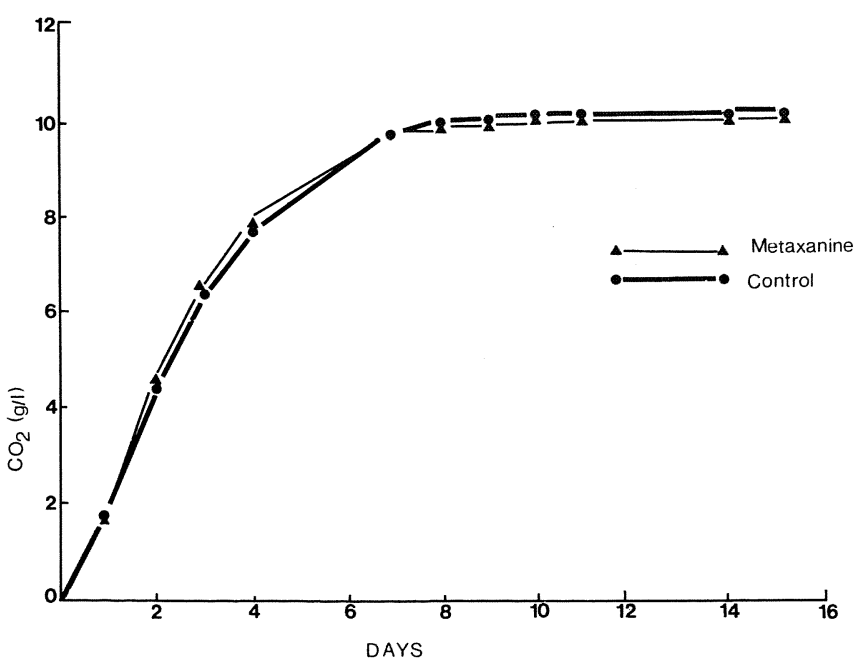

S. Afr. J. Enol. Vitic., Vol. 2. No. 2. 1981 


\section{LITERATURE CITED}

EHRENHARDT, H. \& JAKOB, L., 1968a. Beiträge zur Methodik der Bestimmung von Gärabläufen in Traubenmost unter der Einwirkung von Fungiziden. Weinberg Keller 15, 5-30.

EHRENHARDT, H. \& JAKOB, L., 1968b. Vergleichende Untersuchungen über den Einfluss weinbaulich genutzter Fungizide auf die vergärung von Traubenmosten. Weinberg Keller 15, 355-384.

HARTER, H. L., 1960. Critical values for Duncan's new mulitple range test. Biometrics 16, 671-685.

MARIAS, P. G., 1977. Die beheer van die belangrikste wingerdsiektes. Wynboer 553, 71-74.

MARAIS, P. G. \& VAN DER WALT, H. S., 1978. Trials with systemic fungicide formulations for the control of grapevine downy mildew. Phytophylactica 89-91.
MEYER, M. M. E., BRECHBUHLER, C. H. \& WEBER, J., 1978. Etude des actions secondaries de quelques fongicides anti-Mildiou. Institut Technique De La Vigne Et du Vin.

MUR, G., 1978. Etude de mode d'action des nouveaux fongicides anti-mildiou pénétrants et systémiques. Progrés agric. vitic. 95, 570-585.

RÀGALA, P. \& MINÁRIK, E., 1971. Einfluss von Fungizides auf die Hefeflora der Rebe. Biol. Práce Sek. biol. a lek. vied. 17, 1-124.

SCHILLER, R., RASPÉ, R. \& FITZSCHE, H. W., 1979. Mikol - Das erste vollsystemische Fungizid zur Bekämpfung von Rebenperonospora. Dte Weinb. 34, 453-456.

UNTERSTENHÖFER, G., 1963. The basic principles of crop protection field trials Höfchenbr. Bayer Pflschutz - Nacht. 16, 81-164. 